\title{
ASSESSMENT OF UTILITY SIDE COST SAVINGS FROM BATTERY ENERGY STORAGE
}

\author{
J. T. Alt (S) \\ M. D. Anderson (SM) \\ Department of Electrical Engineering \\ University of Missouri-Rolla
}

\begin{abstract}
Atstract A method of detemining the dynmic operating cast bencfits of energy thorage systems for utility applications is presented. The production costing program DYNASTORE is used to analyze esonomic benefits for "ntility $B$ " an isolated ishad utility, using beuristic nuit commitment algorithms. The unit commitment is done using chronolegic load data and a detalled nodel of the utility characteristics. Seferal wit cummitument scenarios are run for utility $B$, and the results are presented. Comparisons between various Battery Energy Storage System (BDSS) applications, as well as cases with and without battery storage, are shown. Results show that for utility $\mathrm{B}$, a BESS of $300 \mathrm{MW}$ size used for either loud leveling or spirning reserve provides the greatest economic benefit
\end{abstract}

\section{INTRODUCTION}

The primary motivation of this work is to achieve more economical operation of the electric ntility system while enhancing reliability with additional energy sources. To reduce costs during peak demand periods, utilities employ Demand Side Mawagement (DSM) strategies Direct Load Control (DLC) is ove common DSM program which enables the wility to offer customers a rate discount in exchange for ulility control of certain loads such as air conditioners, clothes dryers, and water heaters, in order to curtail power demand during peak periods when electricity is very expensive.

Energy storage is an attractive energy source to augment DSM implementation By using energy storage systems, a lower cost source of electricity $\mathrm{cm}$ be effectively provided to meet the peak demand An energy storage device can be charged during off-peak periods with lower cost sources such as nuclear or coal fired units. This stored encrgy is then used during peak periods so that high cost units such as combustion turbines do not have to serve the losd.

\author{
R. G. Jungst \\ Battery Development Department \\ Sandia National Laboratories \\ Albuguerque, NM
}

For purposes of system security, utilities are required to maintain a certain amount of ready seserve which can be usod when a generating wnit faihure occars. In general, the ready reserve zequirement is a fixed percentage of the peak load, and also must be greater than the capacity of the largest generating mit Because energy storage devices can be ramped from full charge to full discharge almost instantaneousily they can provide a source of instantaneous ready reserve powcr. Utilities also must have a certain amount of capacity online set aside for Load Frequency Contol (LFC). The LFC requirement allows the utility to adjust the power genexation to match fluctuations in the load Energy storage devices (ESD) can be used to satisfy the spinning reserve or frequency regulation requirements, therefore requiring tewer generating units to be synchronized to the grid. Energy storage systems may be used for this purpose include Pumped Storage, Compressed Air Energy Storage (CAES), Superconducting Magnetic Energy Storage (SMRS), and Battery Energy Storage Systents (BESS). This paper will focus on Battery Energy Storage, however many of the concepts explored can be easily extended to include other energy storage facilities.

Many reports have been written regarding various aspects of battery energy storage inclnding battery technologies [1-6], economic benefits of BESS [7-11], BESS dispatch strategies [12-15], BESS power converter system design and control [16-17], and power system security and reliability.

In recent years, the Department or Energy (DOE), the Elcctric Power Research Institute (EPRI), and the Intermational Lead Zinc Research Organization, Inc. (4LZRO) have spent a great deal of time and effort on BESS development. Their intent is to cnable energy customers to casity maike economic decisions regarting the installation of battery storage equipment BECHTEL GROUP, Inc has completed BESS cost studies for EPRY [8] including maintenance, operation, battery, converter, and engineering costs. Other projects $[9,10]$ have developed spreadsheet programs to evaluate the economic value of using a BESS system. These modeis calculate savings from peak shaving and energy displacement using load durarion data, without 


\section{DISCLAIMER}

This report was prepared as an account of work sponsored by an agency of the United States Government. Neither the United States Government nor any agency thereof, nor any of their employees, make any warranty, express or implied, or assumes any legal liability or responsibility for the accuracy, completeness, or usefulness of any information, apparatus, product, or process disclosed, or represents that its use would not infringe privately owned rights. Reference herein to any specific commercial product, process, or service by trade name, trademark, manufacturer, or otherwise does not necessarily constitute or imply its endorsement, recommendation, or favoring by the United States Government or any agency thereof. The views and opinions of authors expressed herein do not necessarily state or reflect those of the United States Government or any agency thereof. 


\section{DISCLAIMER}

Portions of this document may be illegible electronic image products. Images are produced from the best available original document. 
considering the effects of spinning reserve (SR) and LFC requirements. A more accurate method is neoded. One approach is the unit commiment scenario, which offers results that match the time variation of load and includes the effects of $S R$ and LFC for chronological load data.

\section{DEVELOPMENT METHOD}

\section{Production Costing Methodology}

In onder to determine the dynamic operating benefits of energy storage for utility applications, the production costing program DYNASTORE [18] is used. Dynastore has several advantages over previous production costing methods, such as PROMOD III. DYNASTORE uses chronological data instead of load dnration curve dats, which allows staxt up costs, manimmm up time, and minimum down time constraints to be included in the unit commitment process and subsequent cast calculations. DYNASTORE dynamically models the unit commitment and conomic dispatch process over a specified time period and includes the effects of energy storage devices such as BESS, CAES, and SMES. Energy storage system dispatch strategies include load leveling, spinming reserve, and load frequency control. The effects of generating unit maintenance and forced outages are also inchided.

\section{Unit Commitment Algorithms}

DYNASTORE uses heuristic methods to sotve the unit commitment problem rather than algorithmic solution techniques, such as dynamic programming. These include:

a. Input Order Logic

b. Minimum Down Time Logic

c. Economic Shutdown Logic

d. Economic Cycling Logic

After the unit commiment problem has been solved DYNASTORE solves for the economic dispatch using the cqual-incremental-cost criterion. When the storage system is used for load leveling, DYNASTORE creates an incremental cost threshold If the incremental cost is below the threshold and the battery is not fully charged, the storage system will be charged. If the incremental cost is above the threshold and the battery is not folly discharged, the storage system will be discharged

\section{DINASTORE Simutation Mothods}

DYNASTORE provides for several methods of production cost simulation. Those methods are

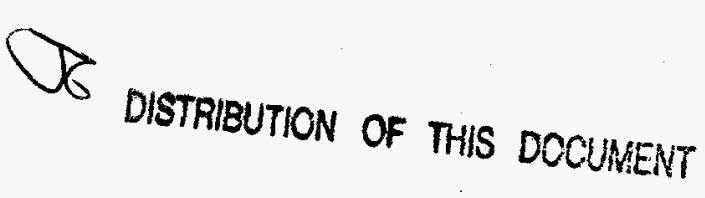

deteministic, standard Monte Carlo, and antithetic Monte Carlo. The difference in cach of these methods concerns the issue of generating unit availability. The detcrministic method assumes that there are no forced ourages. In this method, all generating units are considered to be available at all times, except any units which may be on maintenance outage.

The standard Monte Carlo method uses a pseudo random number generator to simulate random forced outnges based on the generating unit reliability data specified in the input data, namely the Equivalent Forced Outage Rate (EFOR) and the Mean Time To Repair (MTTR).

The antithetic Monte Carlo sampling method improves the convergence of the standard Monte Carlo sampling method. The antithetic Monte Carlo algorithm alternates standard Monte Carlo iterations with antithetic iterations. The antithetic iteration is based on the principle that the variance of two negatively correiated random numbers is less than the sum of the variance of two independent random numbers. During the antithctic iteration, the antithetic of random number generated in the previous standard Mome Cario iteration is used to determine the presem state of each generating unit. If the random number for the standard Monte Carlo sample is $r_{i}$ then the antithetic of that number, $a_{i}=1-r_{i}$, is used for the antithetic sample. This allows for quicker convergence of operating cost calculations.

\section{DESCRIPTION OF TEST SYSTEM}

\section{Utility Characteristics}

The sample utility studied in this project will be referred to as Utility B. Il consists of a single control aree and is isolated from interconnection with other utilities. The system peak loads for the years 1996 and 1997 an $2750 \mathrm{MW}$ and $2850 \mathrm{MW}$ respectively. The meximum generation capacity for the 1996 and 1997 simulation periods is $5135 \mathrm{MW}$, includiting $311 \mathrm{MW}$ of coal fired generation, $3099 \mathrm{MW}$ of oil fired generation, $592 \mathrm{MW}$ of combined cycle gencration, and $1133 \mathrm{MW}$ of gas turbine generation.

\section{Study Parameters}

The operating reserve and spinning reserve requirements are given by the following equations:

$$
\begin{gathered}
O R=L \times P \%+C \times Q \%+R \\
S R=O R \times S \%
\end{gathered}
$$

Where $O R$ represents the System Operating Reserve Requirement (MW), SR represents the System 
Spinning Reserve Requirement (MW), $L$ rcpresents the peak (or hourty) system load (MW), C represenus the capacity of the largest thermal unit (MW), P\% represents a percentage of the peak (or hourly) system loant, $Q \%$ represents a percentage of the capacity of the largest thermal unit, $R$ represents a constant MW value, and $S \%$ represents the percentige of the operaling reserve which must be spinning.

These parameters allow the user to model operating reserve in a variety of ways depending on the requirements necessary to maintain reliability on a specific system. Any combination of one of more of the above parameters may be used to determine the operating reserve requirement. In order to allow for diversity of reserve, DYNASTORE allows the uscr to specify a Maximum \% or Spinning Reserve on Onc Unit. Table I lists values used for key parameters in each of the study cases described herein

\section{PRODUCTION COST RESULTS Sensitivity Analysis}

Effects of BESS on spinning reserve, load leveling,

\begin{tabular}{|l|r|}
\hline \multicolumn{2}{|l|}{ Table I - Paramcters used in DYNASTORE study } \\
\hline P\% & 20 \\
\hline Q\% & 0 \\
\hline$R$ & 0 \\
\hline $\begin{array}{l}\text { Spin \% of Operating } \\
\text { Reserve (S\%) }\end{array}$ \\
\hline Maxinum \% of Spinning \\
Reserve on One Unit & 75 \\
\hline Peas os Instant & 100 \\
\hline Study Period & Peak \\
\hline Unit Commirment Option & Economic shutdown logic \\
\hline
\end{tabular}

and frequency control requirements are considered These test cases have bein based on typieal generator and load data obtained from Utility B. The list of generators includes all units which are to be in service on the specified utility by the beginning of the 1996 calendar year. BESS parameters have heen adjustod to reflect the actual desired application of the batterics. The range of the BESS capacity has been extended from $40 \mathrm{MW}$ to $500 \mathrm{MW}$ in order to detemine the best BESS size. Figures 1 and 2 show that the BESS savings are almost linear from $40 \mathrm{MW}$ to $300 \mathrm{MW}$ for spinning reserve and load leveling respectively but begin to level off above $300 \mathrm{MW}$. A spinning reserve requirement of $15 \%$ of the peak load computes to 412.5 MW for the 1996 simuiation year and 427.5 MW for
1997. Therefore, a minimal increase in operating cost benefits is obtained by increasing the BESS size above $3 \mathrm{Mn} \mathrm{MW}$. While the overall savings levels out, the average savings per $\mathrm{MW}$ decriases above $300 \mathrm{MW}$. This is shown in Figute 1.

A summary of BESS parameters appears in Table II.

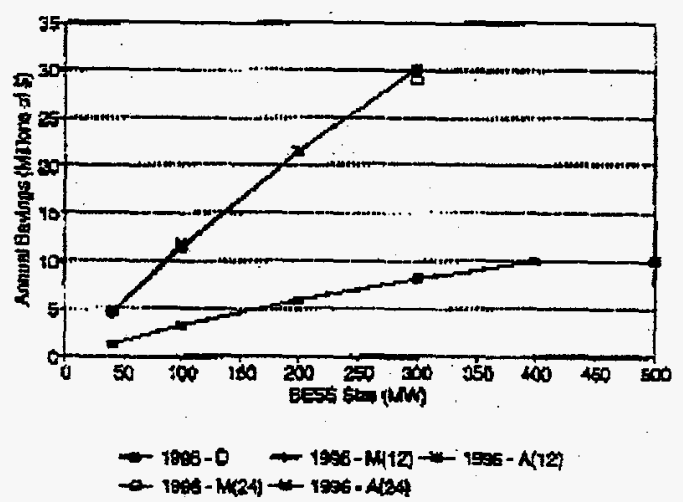

Figure 1: BESS used for Spinning Reserve - 1996

\section{BESS Used For Spinning Reserve}

\begin{tabular}{|l|r|}
\hline \multicolumn{2}{|c|}{ Table II - BESS Parameters } \\
\hline Discharge Capacity & variable $-40 \mathrm{MW}-500 \mathrm{MW}$ \\
\hline Charge Capacity & variable $-40 \mathrm{MW}-500 \mathrm{MW}$ \\
\hline Variable O\&M Cost & $0 \$ \mathrm{MWh}$ \\
\hline Efficiency (ac-dc-ac) & $70 \%$ \\
\hline $\begin{array}{l}\text { Entrgy Storage } \\
\text { Capacity }\end{array}$ & variable $-40 \mathrm{MW}-500 \mathrm{MW}$ \\
\hline
\end{tabular}

Several scenarios have been simulated which show how BESS savings vary with BESS size. In each scenario considercd here, the BESS is used for spinning reserve ondy, and the BESS charge and discharge capacity are varied. Scenarios are run with the deterministic, standard Monte Carlo, and antithetic methods. A summary of operating cost savings for the various spiruing reserve scenarios appears in Table III. A graph of BESS savings vs. BESS size for the 1996 simulation year appeass in Figure 1. It shows that increasing the number of Monke Carlo iterations from 12 to 24 does not produce any noticeable change in savings. Hence, the remainder of the analysis was done using 12 iterations.

\section{BESS Used For Load Leveling}




\begin{tabular}{|c|c|c|c|c|c|c|}
\hline Simulation Method & \multicolumn{2}{|c|}{ Deterministic } & \multicolumn{2}{|c|}{ Monte Cario (12 iterations) } & \multicolumn{2}{|c|}{ Antithetic (12 iterations) } \\
\hline Simulation Year & \multirow[t]{2}{*}{1996} & \multirow[t]{2}{*}{1997} & \multirow[t]{2}{*}{1996} & \multirow[t]{2}{*}{1997} & \multirow[t]{2}{*}{1996} & \multirow[t]{2}{*}{1997} \\
\hline BESS Size (MWh) & & & & & & \\
\hline 40 & 1.232 & 2.845 & 4,534 & 6.205 & 4.743 & 6.232 \\
\hline 100 & 3.168 & 5.411 & 11.247 & 14.803 & 11.533 & 15.248 \\
\hline 200 & 5,890 & 8.584 & 21.313 & 29.023 & 21.530 & 29.498 \\
\hline 300 & 8.083 & 11.483 & 30.366 & 41.106 & 30.181 & 41.260 \\
\hline 400 & 9.865 & 13.720 & \multirow{2}{*}{\multicolumn{2}{|c|}{$\begin{array}{c}\text { Base Case Cost } \\
\text { w/o BESS }\end{array}$}} & \multirow{2}{*}{611.32} & \multirow{2}{*}{690.05} \\
\hline 500 & 9.985 & 14.228 & & & & \\
\hline
\end{tabular}

Several scenarios have been simulated which show how savings vary with BESS size. In each scenario considered here the BESS is used for load lcveling and the BESS charge and discharge capacity are varied It should be noted that if the entire BESS is not neoded for load leveling at a specific instant of time, the remainder will be credited toward the spinning reserve requirement. Sccnarios are nun with the deteministic, standard Monte Carlo, and anlithetic methods. A sumumary of savings for the various load Ieveling scenarios appears in Table IV. A graph of BESS savings vs. BESS size for the 1996 simulation year appears in Figure 2.

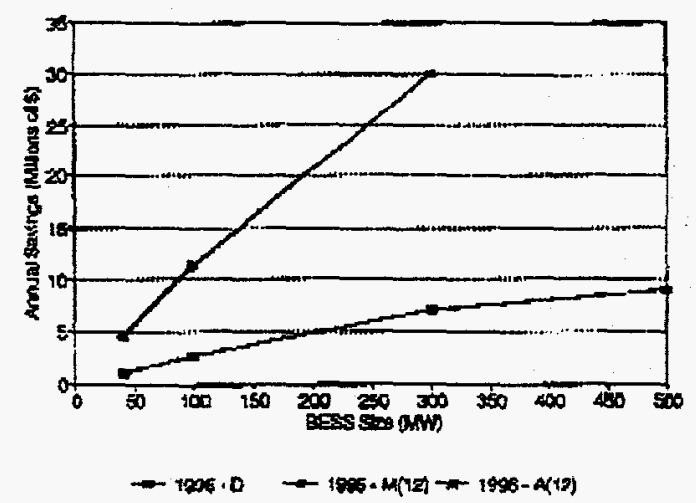

Figure 2: BESS used for Load Leveling - 1996 Sinulation Results

\section{BESS Used For Load Frequency Control}

Several scenarios have been simulated which show how BESS savings vary with BESS size. In each scenario considered here the BESS is used for LFC. and the BESS charge and discharge capacity are varicd. Savings are based on the difference in production cost wher LFC is done with base and cycling anit generators and the production when LFC is done with the BESS. Scenarios are run with the deterministic, standard Monte Carlo, and antithetic methods. A sunmary of savings for the various LFC scenarios appears in Table V. A graph of BESS savings vs. BESS size for the 1996 simulation year appears in Figure 3.

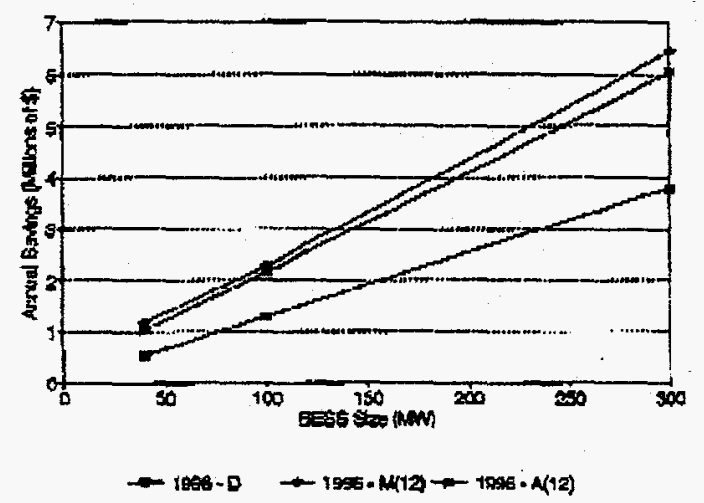

Figure 3: BESS used for Load Frequency Control 1996 Simulation Results

\section{Comparison of BESY Scenarios}

In ordcr to determine the relative benefits of different energy storage scenarios it is useful to compare the savings when energy storage is used for spinning reserve, load leveling and frequency regulation respectively. Graphs of BESS strings vs. BESS size for each energy storagc scenario for the 1996 and 1997 simulation years nsing the standard Monte Carlo method with 12 iterations are shown in Figure 4 and Figure 5 respectively. 
Tablc IV - Summary of annual savings when BESS is used for load leveling (Millions of \$)

\begin{tabular}{|c|c|c|c|c|c|c|}
\hline Simulation Method & \multicolumn{2}{|c|}{ Deterministic } & Monic Carlo (12 iterations) & \multicolumn{2}{|c|}{ Antithetic (12 iterations) } \\
\hline Simulation Year & 1996 & 1997 & 1996 & 1997 & 1996 & 1997 \\
\hline BESS Size (MWh) & & & & & & \\
\hline 40 & 1.093 & 2.596 & 4.395 & 6.099 & 4.667 & 6.187 \\
\hline 100 & 2.669 & 4.975 & 11.051 & 14.546 & 11.370 & 15.092 \\
\hline 300 & 7.143 & 10.424 & 29.940 & 40.618 & 30.061 & 41.114 \\
\hline 500 & 8.994 & 13.419 & & & & \\
\hline
\end{tabular}

Table V - Summary of annual savings when BESS is used for load frequency control (Millions of \$)

\begin{tabular}{|c|c|c|c|c|c|c|}
\hline Simulation Method & \multicolumn{2}{|c|}{ Deterministic } & Monte Carlo (12 iterations) & \multicolumn{2}{c|}{ Antithetic (12 iterations) } \\
\hline Simulation Ycar & 1996 & 1997 & 1996 & 1997 & 1996 & 1997 \\
\hline BESS Stze (MWh) & & & & & & \\
\hline 40 & 0.535 & 0.596 & 1.160 & 1.362 & 1.021 & 1.136 \\
\hline 100 & 1.301 & 1.450 & 2.281 & 2.521 & 2.158 & 2.350 \\
\hline 300 & 3.805 & 4.307 & 6.443 & 7.264 & 6.051 & 6.985 \\
\hline
\end{tabular}

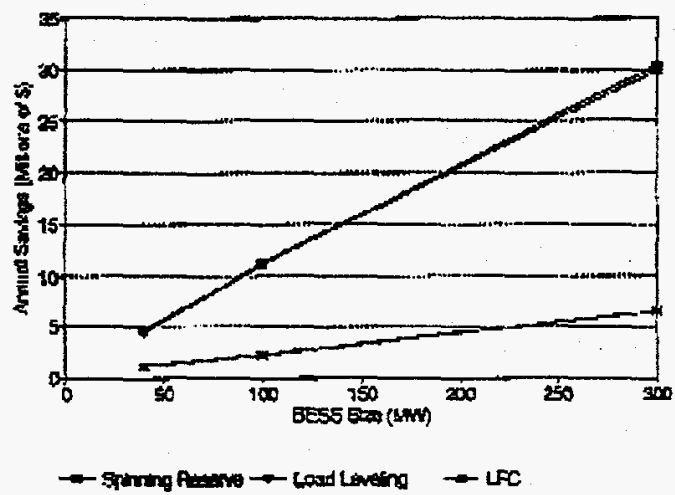

Figure 4: Comparison of BESS Strategies - 1996 Monte Carlo Simulation Results

Nolice that the savings when the BESS is used for load leveling are almost the same as the savings when the BESS is used for spinning reserve. This is a coincidence based on the data for this specific system. In general, the benefits of using a BESS for load leveling and spinning reserve will not be the same. Some insight into the comparison of BESS benerits for these scenarios can be obtained by considering how the BESS benefits are formulated.

When the BESS is used for load leveling, the BESS will be charged during off-peak pcriods when the incremental cost is Low and the BESS will be

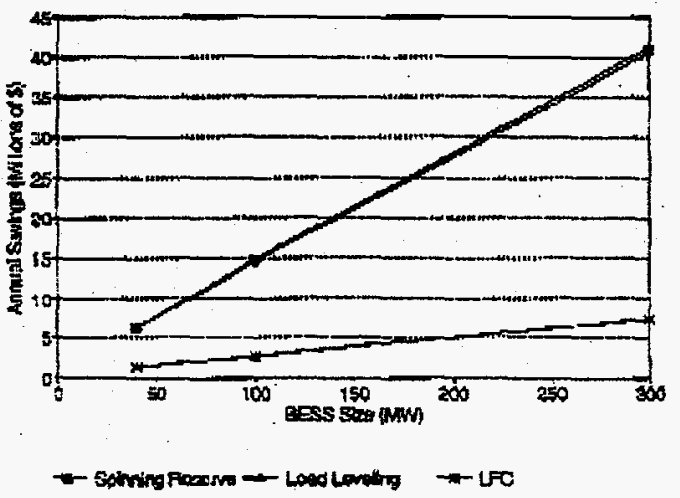

Figure 5: Comparison of BESS Strategies - 1997 Monte Carlo Simulation Results

discharged during on-peak times when the incremental cost is thigh. The relative production cost of various generaning units with respect to one another will affect the relative incremental cost and hence. the overall savings. Some energy is lost in the conversion of ac power to de power stored in the BESS and the conversion back to ac power: In order to ensure that the BESS provides savings, the ratio of incremental cost during charging to incremental cost during discharging must be less than the efficiency of the entire ac-do-ac cycle. 


\section{BESS Used For Multiple Scenarios}

In addition to the system characteristics which have been used for previous cases, consider the BESS used on combinations of load leveling, spinning reserve, and load frequency control. Each of the following three cases has a combined total of $100 \mathrm{MW}$ of either generarors on LFC or BESS on LFC or a combination thereof. In each of these cases the total BESS capacity is $100 \mathrm{MW}$. The three cases to be considered are (1) when the BESS is used for $50 \mathrm{MW}$ of lasd leveling and $50 \mathrm{MW}$ of spinning reserve, (2) when the BESS is used for $50 \mathrm{MW}$ of load leveling and $50 \mathrm{MW}$ of LFC, and (3) when the BESS is used for 50 MW of spinaing reserve and $50 \mathrm{MW}$ of LFC. A summary of the savings when the BESS is used for each of these cases appears in Table VI. These savings are compared with the savings shown in Tables III, IV, and $V$ respectively. The results show that the optimum comunitmen scenario includes the BESS implementation for both SR and LL.

Table VI - Summary of annual savings when BESS is used for some combination of load leveling, spinning reserve, and LFC stratcoics (Millions of S)

\begin{tabular}{|l|c|c|}
\hline Strateg & 1996 & 1997 \\
\hline $\begin{array}{l}\text { BESS used for 50 MW of LL } \\
\text { and 50 MW of SR }\end{array}$ & 12.215 & 15.918 \\
\hline $\begin{array}{l}\text { BESS used for 50 MW of LL } \\
\text { and 50 MW of LFC }\end{array}$ & 6.569 & 8.778 \\
$\begin{array}{l}\text { BESS used for 50 MW of SR } \\
\text { and 50 MW of LFC }\end{array}$ & 6.700 & 8.939 \\
\hline
\end{tabular}

\section{v. CONCLUSIONS}

The results presented illustrate that economic benefits can be obtained by utilizing energy storage for spinning rescove, load leveling and frequency control. It is shown that the greatest economic benefit of storage will be obtained when the BESS is used for load leveling and/or spinning reserve. The operating benefits of using the BESS for load frequency control on this utility are much less than spinning reserve or load leveling. For this particular simnlation period for this particular utility, the connomic benefits of using a BESS for load leveling and spiming reserve are nearly idcntical. As fuel prices fluctuatc this relationship may change in favor of one scenario or the other. However it was shown that a 300 MW BESS nised in any combination of load leveling and spinning reserve will bave the most savings per MW BESS capacity. Rccall that the economic benefits of the BESS begin to saturate above $300 \mathrm{MW}$ for both load leveling and spiming reserve applications. This suggests that if a BESS larger than $300 \mathrm{MW}$ is chosen it should be ensured that neither the portion used for spinning reserve, nor the portion used for load leveling exceeds $300 \mathrm{MW}$ in order to aclieve maximum benefit.

\section{Acknowledgements}

The anthors wish to thank Sandia. National Laboratories which is supported by the U.S. Department of Energy under contract DE-ACO4 -94AL85000; also the forelligent Systcms Center at the University of Missouri-Rolla Appreciation is extended to EPRI and Steve Eckroad for DYNASTORE and to Stephen Loc. its developer, for their help and patience.

\section{References}

(1) Pivec, A., B.M. Radimer, E.A. Hyman, "Utility Operation of Battery Energy Storage al the BEST facility," IEEE Transactions on Energy Conversiom, Vol. 1, No. 3, pp. 41-46, 1986.

[3] Eckroad, S., B. Radimer, "Review of Enginering Design Considerations for Battery Energy Maragement Systems," IEEE Transactions on Energy Conversion, Vol.6 No. 2, pp. 303-309, June 1991.

[3] Salameh, Z.M., MA. Cassacea, W. A. Lynch, "A Mathematical Model for Lead Acid Batteries." IEEE Transactions on Energy Conversion, Vol. 7, No. 1, pp. 93-97, 1992.

[4] Cassacea, M.A., ZM. Salameh, "Determination of Lead-Acid Battery Capacity Via Mathematical Modeling Techniques," IEEE Transactions on Energy Corversion, Vol. 7, No. 3, pp. 442-446, 1992.

[5] Anderson, M.D., D.S, Carr, "Battery Energy Storage Technologies," Proceedings of the IEEE. Vol. 81, No. 3, pp. 475-479, March 1993.

[6] Ball, G.J., G.Corey, B.L. Norris, "Government, Industry, and Utility Development and Evaluation of a Modular Utility Battery Energy Storage System," To appear in IEEE Transactions on Energy Conversion (Paper No. 95 WM 085-1 EC).

[7] Stolte, W.J., S.W. Eckroad, "Updated Cost Estimate and Berrefit Analysis of Customer-Owned Battery Energy Storage," EPRI EM-3872 Projcet 1175-12, Interim Report, Januaty 1985. 
[8] Electric Power Research Institute, Design and Costs Ior a Generic 10-MW Utility Lead Acid Bantery Energy Stotage Plant," EPRI Report AP-5845, by BECHTEL GROUP Inc., June 1988.

[9] Reckrodt, R.C., M.D. Anderson, R.M Klucany, "Economic models for Battery Energy Storage: Improvements for Existing Models," IEEE Transactions on Energy Conversion, Vol 5, No. 4, pp. 659-665, December 1990.

[10] Anderson, MD., LB. Wiles, R Klucziy, S. Eckroad. "Economic Models for Battery Energy" Srorage," Procedings of the Frontier of Power Conference, Oklaboma State University, Stillwater, OK, October 1992.

[11] Lee, T.Y., N.C. Chen, Detemination of Optimal Contrat Capacities and Optimal Sizes of Battery Energy Storage Systems for Time of Use Rates Incustrial Customers," To appear in EEEE Transactions on Energy Conversion (Paper No. 95 WM 087-7 EC).

[12] Kuniseh, H.J. K.G. Kramer, H. Dominik, Battery Energy Storage, Awother Option fot Load-Frequency-Control and Instantaneors Reserve," IEEE Transactions on Energy Conversion, Vol. 1, No. 3, pp. 41-46, 1986.

[13] Hurwitch, J.W., C.A. Carpenter, "Tcchnology and Applications Options for Future Battery Power Regulation," IEEE Transactions on Energy Conversion Vol. 6, No. 1, pp. 216-223, March 1991.

[14] Anderson, M.D., RM. Kluczny, L.B. Wiles, S.W. Eckroad, "Lead-Acid Batteries for Customer Peak Sbaving," IIZRO Project No. LE-373, Final Report, July 1991.

[15] Kottick, D., M Blaul, D. Edelstein, "Battery Energy Storage for Frequency regulation in an Island Poprer System," IEEE Transactions on Energy Conversion, Vol. 8, No. 3, pp. 455-459, 1993.

[16] Beck, I.W., D.P. Caroll G.E Gareis, P.C. Krause, and CM Ong, "A Computer Stady of Battery Energy Storage and Power Conversion Equipmen Operation," IEEE Transactions on Power Apparatus and Systems, Vol. 95, No. 4, pp. 1064-1072, 1976.

[17] In, C.F., C.C. Liu, C.J. Wu, "Effect of Battery Encrgy Storage System on Load Frequency
Contral Considering Governor Deadband and Generation Rate Constant,". To appear in IEEE Transactions on Energy Conversion (Paper No. $95 \mathrm{WM}$ 086-9 EC).

[18] User's Manual for DYNASTORE 4.0; A Compater Model for Quantifying Dynamic Energy Storage Benefits, Research Projict 3116-1, TR-103480, Final Report, November 1993.

\section{Biographies}

John Timokhy Alt (891) was bon in Kirkwoad, Mispouri on Auggus 18. 1971. He received his BSFE, Cun Lauder from the University of Misenari-Columbia in 1992 atdi his MSIE in the area of Power Systems and Electric Machinery from the Iniversity of 2assouri-Rolla in 1955. Protrty Mr. Ath is pursing the PhD. dagree in clectried! eaginuecing of the University of Missouri-Rolla. Mr. Alt is a thuded member of LEEE and PES and a member of Tau Beta Pi and Eas Kappa Nu.

Max D. Anderson (M67, SM8O) received the B.S.E.E. and M.S.E.E.

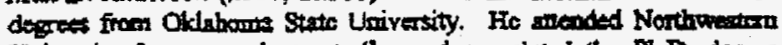

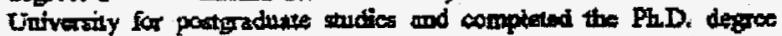
from Arizona State Univerity in 1967. After 13 yeurs of enginocrint

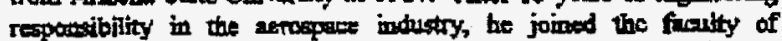

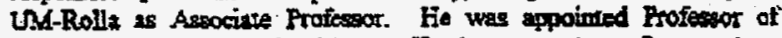
Electrical Enginearing in 1982. He bis served as Powrer Arte Coondinator for 10 years.

Dr. Andersoc's rosearch interests lie in the areas of electric utility systems desiga and operation Sppeific vood includes viandization

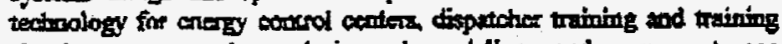

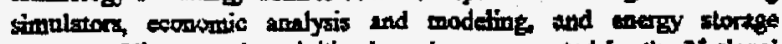
syeterese Hils research activities have been supported by the National

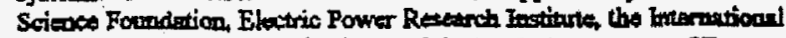
$L=a d 2$ inc Reseant Ongtivation, and the U. \&. Departeneat of Enory. Dr. Andersen bas over 50 rechnical putlientions and be thes had over

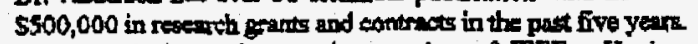

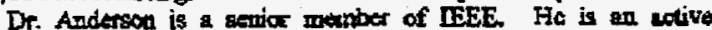

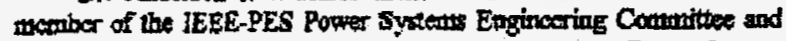
the following guboonutiteos and working groupe: 1) Power Systen

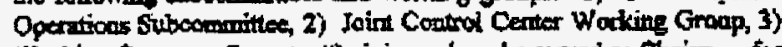
Working Group on Operator Iraining, where he served as Chairmm for 10 years and 4) Full Graphies Working Group. He has been responsible for paper sasions, panel sections and workshops for theas groups in addition he is a reviewer of tectnical papers for the IEEE-PES sanmer and wimer moetiogs, and suinseque it publicution in the IEEE Transacdion on Fown Systems. Ile is past Chnirmin of the Rolla Subsection of the IFEE.

Ho is a necuber of Tan Bets Pi, Ek Kappa Nu, Sigme Xi and a

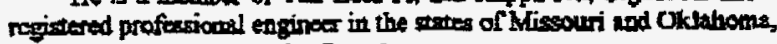
and the province of Onitio, Caradi.

Pudoleh G. Jungst rocetved his B.A degres from Inther College in 1968 and completed studies for the PLD. degree in inerganic chamikty at the Uimiversity of Ifinois in 1976. Di. Junges is a Sewiur Mernber of

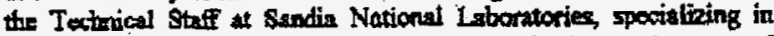
energy coupnentis His recert work has baen in the developorient of

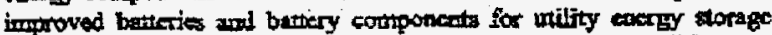
systems battery recycting and thenonl analysis of bettery facilities. Fie is a mernber of tha American Chemical Society. 